\title{
Ascomycetes on Nordic Lycopods
}

\author{
LENNART HOLM and KERSTIN HOLM
}

\begin{abstract}
HOLM, L. \& HOLM, K. 1981: Ascomycetes on Nordic Lycopods. - Karstenia 21: $57-72$.

The ascomycete flora of some Lycopodium species ( $L$. annotinum, L. clavatum, $L$. alpinum, $L$. complanatum s.lat., $L$. selago) has been investigated, mainly on the basis of Nordic, particularly Swedish, material. These species have proved to harbour a rich mycoflora, largely confined to the club mosses and in many cases even restricted to a certain host species. The lycopods studied differ significantly with regard to their fungi. The origin of this mycoflora is discussed. It is considered to be fairly modern and apparently the lycopods were once colonized by fungi inhabiting other xerophytic plats, like Ericaceae and Juniperus.

Twelve Discomycetes and 13 Pyrenomycetes are dealt with and the following new names are published: Discomycetes: Cryptodiscus anguillosporus L. \& K. Holm, n.sp., Dasyscyphus inopinatus (Kirschst.) L. \& K. Holm, n.comb., Hyalopeziza pani (Vel.) L. \& K. Holm, n.comb., Hyalopeziza rubefaciens L. \& K. Holm, n.sp., ?Micropeziza diphasii L. \& K. Holm, n.sp., Pseudopeltis perminuta L. \& K. Holm, n.sp. Pyrenomycetes: Gibbera lycopodii L. \& K. Holm, n.sp., Massarina chamaecyparissi (Rehm) L. \& K. Holm, n.comb., Phaeosphaeria marciensis (Peck) L. \& K. Holm, n.comb., Venturia lycopodina L. \& K. Holm, n.sp.

Lennart and Kerstin Holm, Institute of Systematic Botany, University of Uppsala, P.O. Box 541, S-751 21 Uppsala, Sweden.
\end{abstract}

\section{Introduction}

Lycopodium s.lat. is a cosmopolitan genus of roughly 400 species. The great majority of them are wholly unexplored with regard to their mycoflora. Actually, our knowledge in this field is almost entirely restricted to a few boreal species but even these have not been much scrutinized for fungi. Some 50 fungal taxa have so far been reported on Lycopodium, most of them little known and recorded only once. Few mycologists have paid more than casual attention to these plants; among them particularly C.H. Peck in North America and F. Petrak in Europe.

As a part of our studies of the fungi on pteridophytes, we have also examined the club mosses, which have proved to harbour a rich and higly specific mycoflora. There are in Scandinavia 6 (or 7) species of Lycopodium, representing 4 taxonomic groups recently often treated as separate genera in Europe, viz. Lycopodium s.str., with L. annotinum and L. clavatum, Lepidotis (L. inundatum), Huperzia (L. selago) and Diphasium, with L. alpinum and L. complanatum (including L. tristachyum). Among these species L. inundatum stands apart by its ecology, being a semiaquatic plant, confined to margins of lakes and similar wet places. It is comparatively rare in most parts of Scandinavia and we have had little opportunity to study its fungi. It is our impression, however, that $L$. inundatum has little in common with its congeners, as far as fungi are concerned, and it is not dealt with here.
The other Nordic Lycopodia generally grow in more or less dry coniferous forests, except $L$. alpinum, which is a plant of alpine and subalpine heaths. $L$. annotinum, too, and particularly $L$. selago reach high up in the mountains. In our experience the latter species is not very attractive to fungi.

The present article is mainly based on our own collections, including those of cooperative friends and relatives. In addition the material in $\mathrm{H}, \mathrm{S}$ and UPS has been examined; further some specimens, mainly types, have been obtained on loan from B, BP, C, HBG, K, NYS, and PRM. If nothing else is stated, the cited material is collected by us, and preserved in UPS.

The following account is by no means exhaustive. We have seen more species, but as the material of these was inadequate to allow us to get acquainted with them, they are not introduced here, though some of them may be true Lycopodium fungi. Nevertheless, we believe that most of the common Nordic Ascomycetes are included, and also that many of these species are fairly coextensive with their hosts.

The Imperfecti are respectfully omitted, owing to our very imperfect knowledge of them. On the whole they are considerably less frequent than the teleomorphs, at least in the lowlands, the main exception being Ceuthospora lycopodii, which is one of most common microfungi on lycopods, except on L. selago. Epicoccum sp. seems to be fairly common, too. 
Coniothyrium cf. lycopodinum and a Diplodina have been met with a few times, on $L$. annotinum and $L$. clavatum, and so has Coleophoma cf. empetri on $L$. selago.

\section{Artificial key}

1. Discomycetes . . . . . . . . . . . . 2 2

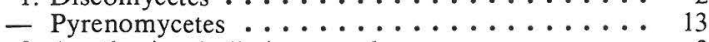

2. Apothecia wholly immersed ......... 3

- Apothecia erumpent or superficial ........ 4

3. Spores vermiform ..... Cryptodiscus anguillosporus

- Spores fusiform .......... Cryptodiscus $\mathrm{sp}$.

4. Apothecia distinctly hairy .......... 5

- Apothecia glabrous or almost so ........ 8

5. Hair asperulate, brown ..... Dasyscyphus inopinatus

- Hairs smooth, mostly hyaline ......... 6

6. Apothecia brownish, hairs 'glassy', straight .... $\ldots \ldots \ldots \ldots \ldots$ Hyalopeziza rubefaciens

- Apothecia whitish, hairs uncinate ........ 7

7. Hairs thin-walled ... Hamatocanthoscypha laricionis

- Hairs solid ........... Hyalopeziza pani

8. Apothecia sessile ............. 9

- Apothecia stipitate .............. 12

9. Scutellum present, excipulum reduced ...... 10

- Scutellum absent, excipulum well developed Mollisia sp.

10. Apothecia usually circular in surface view ..... 11

- Apothecia usually elliptic in surface view, opening by a longitudinal slit ....... Pseudopeltis perminuta

11. Scutellum subcuticular, shining black, opening with persistent flaps ............ Phacidina gracilis

- Scutellum supracuticular, dark brown, disappearing early ....................... Propeziza diphasii

12. Spores ellipsoid ....... Poculopsis ogrensis

- Spores narrowly fusiform .... Cyathicula cyathoidea

13. Ascocarps setose ................ 14

- Ascocarps glabrous . . . . . . . . . . . 16

14. Ascocarps superficial . . . . . . . . . 15

- Ascocarps immersed ....... Venturia lycopodina

15. Asci unitunicate, spores fusiform .. Niesslia haglundii

- Asci bitunicate, spores ellipsoid .. Gibbera lycopodii

16. Spores with transverse septa only ........ 17

- Spores muriform ........ Pleospora islandica

17. Spores 1 -septate ... . . . . . . . . 18

- Spores with 2 or more septa . . . . . . . . 22

18. Septum near the base, asci unitunicate Pseudomassaria lycopodina

- Septum (sub)median, asci bitunicate ...... 19

19. Spores strongly guttulate, $>20 \mu \mathrm{m}$ long Massarina chamaecyparissi

- Spores $<15 \mu \mathrm{m}$ long . . . . . . . . . . 20

20. Interascal threads present, spores obtuse Venturia lycopodina

- Interascal threads absent ............ 21

21. Ascocarps generally densely grouped, spores pointed ........... Mycosphaella lycopodii-annotini - Ascocarps scattered, spores obtuse Mycosphaerella lycopodii

22. Spores with $(2$ or $) 3$ septa ............ 23

- Spores with 5 or more septa .......... 25

23. Spores long hyaline, fusiform Massarina chamaecyparissi

- Spores yellow-brown, ellipsoid ......... 24

24. Ascocarps in the spikes, spores eguttulate .... .............. Phaeosphaeria lycopodina - Ascocarps in the leaves, spores guttulate Phaeoshaeria marciensis 25. Spores with 1 inflated, submedian cell Phaeosphaeria fuckelii - Spores with 1 inflated, supramedian cell ...... .............. Phaeosphaeria herpotrichoides

\section{Discomycetes}

Cryptodiscus anguillosporus L. \& $\mathrm{K}$. Holm sp.nova - Figs. 1a, 2, 8

Apothecia immersa, sparsa, orificio fere rotunda $0.2-0.3$ mm diam. Excipulum vulgo $15-20 \mu \mathrm{m}$ latum, e cellulis minutis, c. $2 \mu \mathrm{m}$ diam., pariete hyalino, sat crasso; margo intus filamentis brevibus ad instar periphysium. Asci fere cylindracei, 35-45(-50) $\times 4-5 \mu \mathrm{m}$, apice incrassati, octospori, 1-. Sporae vermiformes, $20-28 \times 1 \mu \mathrm{m}$, guttulis paucis. Paraphyses filamentosae, c. $1 \mu \mathrm{m}$ diam., septatae, apice vix incrassatae, 1 -

Habitat in Lycopodio complanato emortuo, praecipue in pagina inferiore surculorum.

Typus: Suecia, Uplandia, Dalby pr. Hammarskog, 29.VI.1980 K. \& L. Holm 1893a (UPS, holo).

It is somewhat surprising to come across a Cryptodiscus on this type of substratum, as otherwise it is mainly a genus of lignicolous fungi. However, the present species is a perfectly good Cryptodiscus, though distinguished by the scolecospores. It is probably not infrequent; besides the type we have 7 collections, all from Sweden:

Uppland:Dalby par., pr. Hammarskog, 5.XII.1979, 1767d; 28.VII.1980, 2016d; 16.XI.1980, 2272a. -Västmanland: Västerfärnebo, 20.XI.1980 Rosén. - Dalarna: Garpenberg, Mt Prästberget, 31.V111.1974 Lundqvist 8677. Sundborn, pr. Mjölnarvallen, 30.VIll.1980 Rosén. - Torne Lappmark: Gällivare, Mt Dundret, VIl.1930 Lind.

\section{Cryptodiscus sp.}

- Fig. 1b

On an old herbarium sheet of L. alpinum (vide infa) we have found a Cryptodiscus externally similar to the preceding species but with quite different spores: they are fusiform - somewhat clavate, $8-10 \times 1.5 \mu \mathrm{m}$, finally with $1-2$ (or more?) septa. This collection may represent a species of its own, possibly restricted to $L$. alpinum.

Sweden. Dalarna: Idre, Mt Städjan, 24.11.1893 Hellsing.

\section{Cyathicula cyathoidea (Bull. ex Mérat) Thümen} - Figs. 9, 11

Helotium Sommierianum Magnus, N. Giorn. Bot. Ital. 25:108 (1893). - Type: Siberia, pr. Samarova, 'in spica annotina L. clavati', 18.VII. 1880 Sommier (HBG!).

Helotium lycopodinum Moesz \& Smarods in Moesz, Bot. Közlem. 39:188 (1942). - Type: Latvia, Madona, pr. Vestiana, in dead spikes of $L$. clavatum, 10.VIIl. 1940 Rasins (BP!).

As far as we know, this common and polyphagous fungus has not been recorded on Lycopodium. However, the two taxa cited above in synonymy, obviously belong to this possibly collective species. We have examined the types, which are well developed and seem to match $C$. cyathoidea in every respect. It should be noticed that the original description of $\mathrm{He}$ lotium sommierianum is erroneous in one essential detail: the spores are said to be cylindraceous ('elongato-baculiformes'), whilst they are actually fusiform. Apparently because of this misleading statement, Moesz did not identify his fungus with that of Magnus, but described it as new. Neither he nor Magnus considered Cyathicula in their discussion.

Neither of these two Helotium 'species' has been recorded since first published and we would hardly have dealt with them here, had we not made the find 


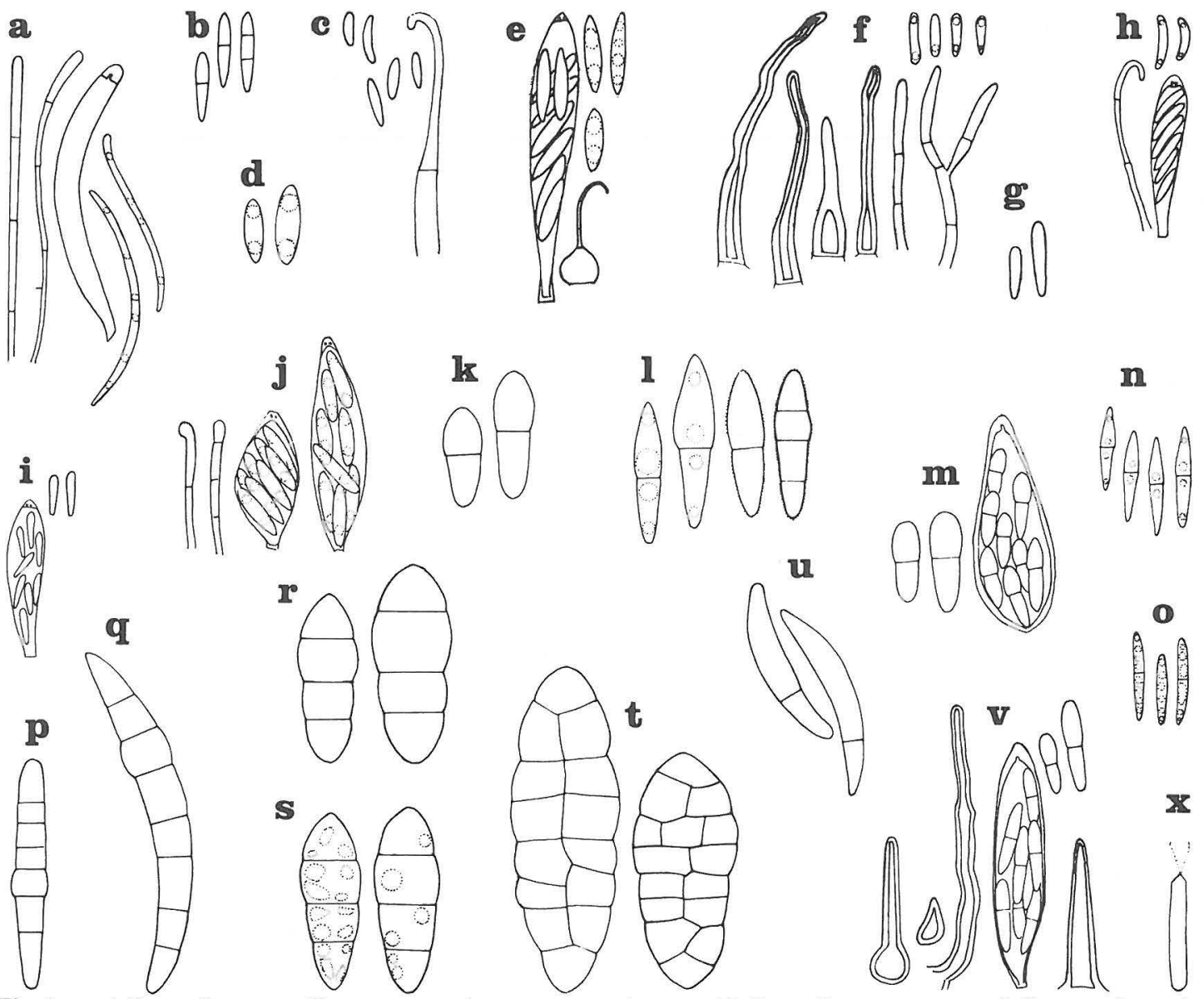

Fig. 1. - a) Cryptodiscus anguillosporus; paraphyses, ascus, and spores, b) Cryptodiscus sp.: spores, c) Hamacanthoscypha laricionis: spores and hair, d) Dasyscyphus inopinatus: spores, e) Hyalopeziza pani: ascus, spores, and hair, f) Hyalopeziza rubefaciens: hairs, paraphyses, and spores, g) Mollisia sp.: spores, h) ?Micropeziza diphasii: paraphysis, ascus, and spores, i) Phacidina gracilis: ascus and spores, j) Pseudopeltis perminuta: paraphyses and asci with spores, k) Gibbera lycopodii: spores, 1) Massarina chamaecyparissi: two immature and two fully mature spores, m) Mycosphaerella lycopodii: spores and immature ascus, n) Mycosphaerella lycopodii-annotini: spores, o) Niesslia haglundii: spores, p) Phaeosphaeria fuckelii: spore, q) Phaeosphaeria herpotrichoides: spore, r) Phaeosphaeria marcyensis: spores, s) Phaeosphaeria lycopodina: spores, t) Pleospora islandica: spores, u) Pseudomassaria lycopodina: spores, v) Venturia lycopodina: setae, ascus, and spores, x) Ceuthospora lycopodii: conidium. - All $\times 1000$.

quoted below. This material is abundant, with the previous year's spikes heavily infested. The apothecia are quite immature but undoubtedly represent the same species as the colletions just mentioned. Certainly the repeated occurrence on lycopod spikes is noteworthy and perhaps this is a particular strain, specialized to $L$. clavatum. We leave this question to a future monographer of Cyathicula.

Sweden. Uppland: Dalby, c. $1 \mathrm{~km}$ W of Högby, dead spikes of L. clavatum, 27.1V.1975, 474a.

Poculopsis ogrensis Kirschst.

- Figs. 5, 10

Kirschstein, Ann. Mycol. 33:204 (1935). - Allophylaria ogrensis (Kirschst.) Dennis, Persoonia 3:57 (1964). - Type: Latvia, Ogre, L. clavatum, 3.VIII.1933 Kirulis (B!).
Apothecia scattered, epiphyllous, distinctly stipitate, disc $0.3-0.5 \mathrm{~mm}$ wide, yellow when young, darkening with age subgelatinous when wet. Asci cylindrico-clavate, 120-130 $\times 15 \mu \mathrm{m}$, somewhat narrowed toward the flattened apex, 8-spored; ascus wall considerably thickened at tip, with a minute ring, It. Spores ellipsoid, $20-25 \times 8-12 \mu \mathrm{m}$, hyaline in ascus with 1 or 2 oil globules, then smoky grey and lastly dark brown, sometimes with a germ pore. 1-celled, or finally 2-celled. Paraphyses cylindrical, apically branched, enlarged at the tips to $3 \mu \mathrm{m}$.

Saprophytic in dead L. annotinum and L. clavatum.

It is particularly noteworthy that the spores eventually turn dark brown and develop a septum. These hitherto overlooked facts indicate the true taxonomic position. The spore type strikingly recalls Phaeangellina empetri and there can be no doubt of the affinity. Closely related is also the genus Chloroscypha, on 
Cupressaceae, which agrees perfectly in most essential characters; the main difference is in the excipular hyphae, which are considerably less gelatinized in $\mathrm{PO}-$ culopsis.

$P$. ogrensis has to the best of our knowledge been recorded only once since described, viz. from Norway, by Dennis (1964). It is a rather common species, though, and we have found it in 17 samples from Sweden (Uppland, Dalarna, Hälsingland, Härjedalen, Torne Lappmark).

\section{Mollisia sp.}

- Figs. 1g, 12

Apothecia scattered - thinly grouped, up to $0.5 \mathrm{~mm}$ in diam., externally almost black, hymenium grayish. Asci c. 40 $\times 5 \mu \mathrm{m}$, cylindrico-clavate, 8 -spored, J+. Spores narrowly clavate, $7-10 \times 1.5-2 \mu \mathrm{m}, 1$-celled, hyaline. Paraphyses thread-like, dissolving early.

Fairly common in withering, grayish parts of Lycopodium spp., preferably in spikes and culms.

This species seems to be distinguished by the small, clavate spores and the dark apothecia, but we do not venture to name it, having too much respect for the genus. Possibly it is a true Lycopodium fungus. Mollisia lycopodii Le Breton \& Malbranche (1884:130) is obviously something else, to judge from the description. Our efforts to trace authentic material of that species have unfortunately been without success. According to the kind information of Mr. Michel Lerond, it is not kept in the herbarium of Malbranche and Le Breton in the Muséum de Rouen.

\section{Micropeziza? diphasii L. \& K. Holm sp.nova} - Figs. 1h, 13 Typus: Suecia, Dalarna, paroecia Folkärna, pr. Korskrogen, L. complanatum, 16.X.1980 K. \& L. Holm 2216f (UPS, holo).

Apothecia superficialia, sparsa - laxe gregaria, $80-100(-120) \mu \mathrm{m}$ diam., primo tecta scutello unistrato e cellulis meandriformibus usque $12 \mu \mathrm{m}$ longis, $2-4 \mu \mathrm{m}$ latis in seriebus radiatis dispositis, mature centro dehiscenti, reliquiis collum fuscum hymenium cingentem formantibus. $E x-$ cipulum saepe fere nullum, sed interdum basaliter evolutum, ad $25 \mu \mathrm{m}$ altum e cellulis globosis minutis usque $5 \mu \mathrm{m}$, pariete hyalino \pm incrassato, refringente. Asci vulgo $20-25$ $\times 4-5 \mu \mathrm{m}$, clavati, apice paullo incrassati, annulo minuto ope Iodi et solutione KOH coerulescenti, octospori. Sporae suballantoideae, $5-7 \times 1 \mu \mathrm{m}$, hyalinae, denique guttulatae. Paraphyses ascis longiores, filamentosae, leviter flexuosae, septatae, c. $1 \mu \mathrm{m}$ crassae.

In Lycopodio (Diphasio) complanato sicco, praecipue in pagina inferiore surculorum.

We have put a question mark by the generic name above, owing to the great difficulty of disposing correctly of such a strongly reduced fungs. There are, however, good reasons for assigning it to Micropezi$z a$, cf. Nannfeldt (1976). The general aspect is indicative; so is the scutellum and the supracuticular habit. A distinctive feature of Micropeziza is the excipular structure, composed of cells with thick, hyaline, refractive walls. In $M$. diphasii the excipulum is more or less reduced: the perihymenial part is almost wholly absent and often the basal excipulum, too. The latter can be present in larger apothecia, though, and is mostly made up of very small thin-walled cells, but interspersed among them are larger cells reminiscent of those found in the true Micropezizae. We think that these cells are indicative of the presumed affinity. Anyway we can see nothing that argues against it.

This tiny species often grows intermixed with other dwarfs, like Phacidina gracilis and Psedopeltis perminuta. It is probably common and widespread, but so far is known only from a few place in Sweden and Finland. Besides the type we have seen the following material:

Sweden.Uppland: Dalby, pr. Hammarskog, 19.X1.1979, 1893b and 16.IV.1980, 2016b. Tunaskog, 30.X.1980, 2264c. - Dalarna: St. Kopparberg, 26.VIII.1980, 2234a. Mt Krokforsberget, 6.VIII.1974, 326k. Folkärna, pr. Korskrogen, 23. V11.1979, 1822b and 27.VIII.1980, 2235a.

Finland. Tavastia australis: Loppi, 26.VIIl.1967 Alanko 67-1453d (H).

Dasyscyphus inopinatus (Kirschst.) L. \& K. Holm n.comb.

- Figs. 1d, 3, 4, 14-17

Lachnella inopinata Kirschstein, Ann. Mycol. 36:383 (1938). - Type: Austria, Tyrol, St. Anton, L. annotinum, 5.VIl.1931 Kirschstein (B).

Apothecia scattered, amphigenous, subcuticularly attached, when dry shrivelled up to minute brown, bristly balls, when wet cup-shaped, $0.2-0.3(-0.4) \mathrm{mm}$ in diam., with a short but distinct stipe. Excipulum of textura angularis, densely clad with numerous brown, cylindrical hairs of varying length, up to $120 \mu \mathrm{m}$, and 5-8 $\mu \mathrm{m}$ in diam., obtuse at apex, densely asperulate, sparingly septate. Disc greyish. Paraphyses cylindrical, $2-3 \mu \mathrm{m}$ wide, obtuse at tips, aseptate. $\mathrm{Asci}$ clavate, $40-50 \times 8-10 \mu \mathrm{m}$, with a minute apical ring, I+, 8 -spored. Spores narrowly ellipsoid, $8-10 \times 3-4 \mu \mathrm{m}$, hyaline, with large oil globules, one-celled (or finally 1-septate?).

On dead L.annotinum and L. clavatum.

We have examined the type material, obtained on loan from B, but unfortunately without finding anything corresponding to Kirschstein's description. However, there can be no doubt that his species is the one described here; it is true that he gave the spores as 2-celled, whilst we have seen only aseptate spores, but this discrepancy can be explained: the spores may finally develop a septum, or Kirschstein was the victim of an error of observation: the thin median plasma bridge between the oil drops is easily mistaken for a septum.

The aspect of $D$. inopinatus is suggestive of $D$. pteridis (Alb. \& Schw. ex Fr.) Massee, on ferns, and particularly of $D$. borealis K. \& L. Holm, on juniper. The latter species has narrower spores, and wholly superficial apothecia (Holm \& Holm 1977).

$D$. inopinatus has not been recorded since first described. Nevertheless it is fairly common on L. annotinum, and we have seen material from Sweden (Bohuslän, Uppland, Värmland, Dalarna, Hälsingland, Härjedalen, Lule Lappmark, Torne Lappmark), Norway (Sör-Tröndelag) and Iceland. 

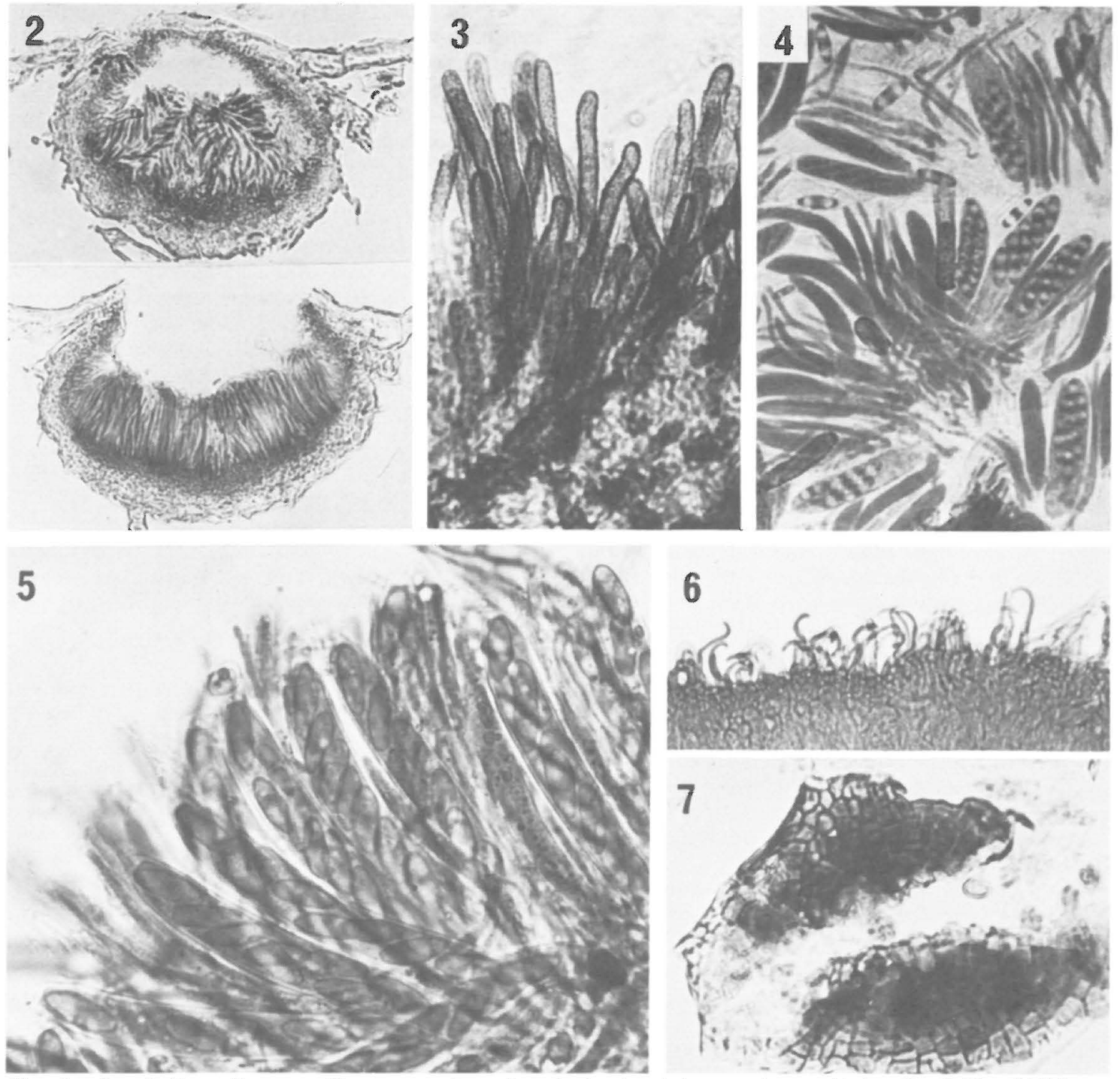

Figs $2-7 .-2$ : Cryptodiscus anguillosporus, sections of apothecia, closed above, and opened below, Lactic Blue, $\times 210 .-$ 3-4: Dasyscyphus inopinatus (3: hairs; 4: paraphyses, asci,spores in Lactic Blue), $\times 530 .-5:$ Poculopsis ogrensis, asci with spores and papraphyses, Lactic Blue, $\times 530 .-6:$ Hamacanthoscypha laricionis, hairs, Lactic Blue, $\times 530$. - 7: Pseudopeltis perminuta, shield, $\times 530$.

Hamatocanthoscypha cf. 1aricionis (Vel.) Svrček - Figs. 1c, 6

Svrček, Česká Mykol. 31:11 (Febr. 1977). - Uncinia laricionis Velenovský, Monogr. Disc. Bohem.: 295 (1934). - Unciniella laricionis (Vel.) K. \& L. Holm, Symb. Bot. Upsal. 21(3):17 (Aug. 1977).

?Hyaloscypha Lycopodii Velenovský, Monogr. Disc. Bohem.: 282 (1934). - Type: Czechoslovakia, pr. Mníchovice, L. clavatum, XI.1929 (PRM, slide 151162!).

Apothecia scattered, c. $0.1-0.3 \mathrm{~mm}$ in diam., whitish with a distinct stipe, c. $0.1 \mathrm{~mm}$ high, brownish at base. Hairs uncinate, generally with 1 septum, up to $40 \mu \mathrm{m}$ long. Paraphyses thread-like, c. $1 \mu \mathrm{m}$ broad. Asci cylindrico-clavate, $25-30 \times 4-5 \mu \mathrm{m}, 8$-spored, $1+$. Spores cylindrical or slightly fusiform or clavate, $5-6 \times 1-1.5 \mu \mathrm{m}$, one-celled, hyaline, eguttulate.

$H$. laricionis is fairly common on coniferous litter. A very similar and perhaps identical fungus has been encountered a few times on Lycopodium. The collections are scanty, the occurrence probably being accidental. Hyaloscypha lycopodii Vel. may be conspecific, to judge from a (poor) slide of the type.

Sweden. Uppland: Dalby, pr. Österbergstorpet, L. complanatum, 19.XI.1979, 1893j, 16.XI.1980, 2272d. - Dalarna: St. Kopparberg, Krokforsberget, 6.VIII.1974, L. complanatum, 326h. Garpenberg, Realsbo, L. clavatum, 29.VIII.1974, 
351d. Folkärna, pr. Korskrogen, L. complanatum, 20.X.1980, 2235f.

Hyalopeziza rubefaciens L. \& K. Holm sp.nova - Figs. 1f, 18, 19

Apothecia sparsa, superficialia, sessilia, pilosa, in humido $0.1-0.2(-0.3) \mathrm{mm}$ diam., discoidea, rufa; in sicco urceolata, fusca, orificio ochraceo. Excipulum basi c. $25 \mu \mathrm{m}$ latum, lateraliter tenuius, pro parte majore e cellulis brunneis fere isodiametris, $5-12 \mu \mathrm{m}$; extus pilis hyalinis crassitunicatis, saepe nonnihil undulatis, (20-)25-35(-40) $\mu \mathrm{m}$ longis, basi c. $4 \mu \mathrm{m}$ apice c. $2 \mu \mathrm{m}$ crassis. Paraphyses filamentosae, interdum ramosae, septatae, c. $1.5 \mu \mathrm{m}$ crassae. Asci cylindrico-clavati, subsessiles, perumque $15-20 \times 4 \mu \mathrm{m}$, octospori, l-. Sporae cylindraceae - subclaviformes, $4-6 \times 1.5$ $\mu \mathrm{m}$, hyalinae, plerumque guttulis terminalibus instructae.

In pagina inferiore surculorum Lycopodii (Diphasii) complanati. Typus: Suecia: Dalarna, St. Kopparberg, pr. Övre Krokfors, 6.VIII.1974, 326b (UPS, holo).

A beautiful species well characterized by the reddish colour appearing when the apothecia turn moist. The substratum is somewhat reddened, too - the place where an apothecium has fallen is marked by a small reddish spot. the hairs are rather variable, see Fig. If. Most of them have a fairly wide lumen, without septa; in others the lumen is very fine save at the apex and base, while some hairs seem to be solid except for the basal part. This variation is noteworthy, particularly in view of the importance attributed to the various hair types in the delimination of genera in the Hyaloscyphaceae. We therefore concur with Korf and Kohn (1980), who unite most of these taxa in a broadly conceived genus, Hyalopeziza. The present species seems best accommodated in the subgenus Unguicularia. al:

Besides the type we have seen the following materi-

Sweden. Dalarna: Kopparberg, pr. Övre Krokfors, 26.VIII.1980, 2234f. Folkärna, pr. Korskrogen, 19.VI.1979, 1580b; 23.VII.1979, 1822a; 8.IV.1980, 2008; 16.X.1980, 2216g; 20.X.1980, 2235d.

Hyalopeziza pani (Vel.) L. \& K. Holm comb.nova - Figs. 1e, 20-22

Hyaloscypha Pani, Velenovský, Monogr. Disc. Bohem.: 285 (1934). - Type: Czechoslovakia, pr. Jevany, L. clavatum, X.1925 (PRM!).

Apothecia scattered or a few together, \pm turbinate, $0.1-0.3 \mathrm{~mm}$ in diam., subsessile or with a short stipe up to $0.1 \mathrm{~mm}$, white, densely and minutely hairy. Excipulum thin at margin, c. $10 \mu \mathrm{m}$ broad, composed of small prismatic cells, towards the base of larger isodiametric cells, up to 15 $\mu \mathrm{m}$; outside clothed with 1-celled hairs, globose at base, c. 5 $\mu \mathrm{m}$ in diam., drawn out above into a solid hair, $10-15 \mu \mathrm{m}$ long and $1 \mu \mathrm{m}$ thick, hooked at the tip. Paraphyses threadlike, c. $1.5 \mu \mathrm{m}$ thick, (dissolving? early). Asci clavate, $36-45$ $\times 7-9 \mu \mathrm{m}$, with a minute apical ring, I+, 8-spored. Spores obtusely fusiform - narrowly ellipsoid, $8-10 \times 2-3 \mu \mathrm{m}$, one-celled, hyaline, with two or more oil droplets. On dead Lycopodium spp.

The above description is made from our material; the identification with Velenovský's species is based on a slide from the type collection (PRM 149707). As stated under $H$. rubefaciens, we have adopted the wi- de generic concept advocated by Korf and Kohn (1980) and refer this species also to Hyalopeziza. It seems best accommodated in the subgenus Unguiculella (as also suggested by Dr. M. Svrček, in litt.) but deviates by the apparent lack of paraphyses with glassy, thickened apex, and cannot be identified with any of the half-dozen species of this group so far known, cf. Raitviir (1970: 37).

This tiny species may be restricted to lycopods, perhaps preferring $L$. clavatum as it is fairly abundant on this host, in nos. 1885 and 2239c. It may occur intermixed with Hamatocanthoscypha laricionis but can generally be recognized under the binocular by the more turbinate almost sessile apothecia, with have a 'downy' appearance whilst those of $H$. laricionis look more hairy. We have seen the following Nordic material:

Sweden. On L. clavatum: - Uppland: Dalby, Tuna skog, 8.X.1979, 1885. Aland, pr. Rövarkulan, 19.IX.1980, 2239c.

On L. complanatum: - Uppland: Dalby, pr. Östbergstorpet, 19.XI.1979, 1893h. - Dalarna: Sundborn, pr. Finnbo. 6.VIII.1974, 326n, and c. $1500 \mathrm{~m} \mathrm{~W}$ of Mjölnarvallen, 30. VIII.1980 Rosén.

Finland. Tavastia australis: Loppi, Hunsala, L. complanatum, 26.V111.1967 Alanko 67-1453(H).

Pseudopeltis perminuta L. \& K. Holm sp.nova - Figs. 1j, 7, 24

Typus: Suecia; Dalarna, St. Kopparberg, pr. Övre Krokfors, L. complanatum, 19.VI.1979 K. \& L. Holm 1731b (UPS, holo).

Apothecia amphigena, subcuticularia, vulgo dense sparsa, desuper visa generatim \pm ellipticae interdum circularia, $50-100(-120) \mu \mathrm{m}$ longa, $40-60 \mu \mathrm{m}$ lata, fissura longitudinali aliquando furcata dehiscentia. Scutellum cellulis radiatum dispositis, centro quadratis ad $5 \mu \mathrm{m}$, margine elongatis usque $8 \mu \mathrm{m}$. Excipulum fere nullum. Asci \pm saccati, subsessiles, $15-27 \times 6-8 \mu \mathrm{m}$, annulo apicali ope lodi et solutione $\mathrm{KOH}$ coerulescenti. Sporae hyalinae, continuae, anguste ellipsoideae vel subcylindricae, $7-9 \times 2 \mu \mathrm{m}$, plerumque guttulis duobus distinctis. Paraphyses ascos subaequantes, septatae, apicem versus leniter incrassatae, c. $2 \mu \mathrm{m}$, diam.

Habitat in surculis emortuis. Lycopodii complanati.

A veritable Lilliputian among the many dwarfs on Lycopodium! Nevertheless it catches the eye as it often occurs in abundance, more or less covering relatively large areas, $1-2 \mathrm{~cm}$ long, on the shoots. It is very characteristic and easily identified by its appearance which recalls a Leptopeltis. As it is so strongly reduced, its taxonomic positions is somewhat uncertain but it seems to fit in well in Pseudopeltis, a genus recently established for a similar fungus on ferns, $P$. filicum (Holm \& Holm 1978). There is close agreement in essential characters, like the structure of the scutellum and asci.

$P$. perminuta is a true inhabitant of $L$. complanatum, and seemingly restricted to this host. It is certainly much more common and widely distributed that can be inferred from our comparatively few collections, but is possibly a northern species.

Sweden. Dalarna: St. Kopparberg, pr. Övre Krokfors: 6.VIII.1974, 326m; 19.VI.1979, 1731b; 26. VI11.1980, 2234c; 

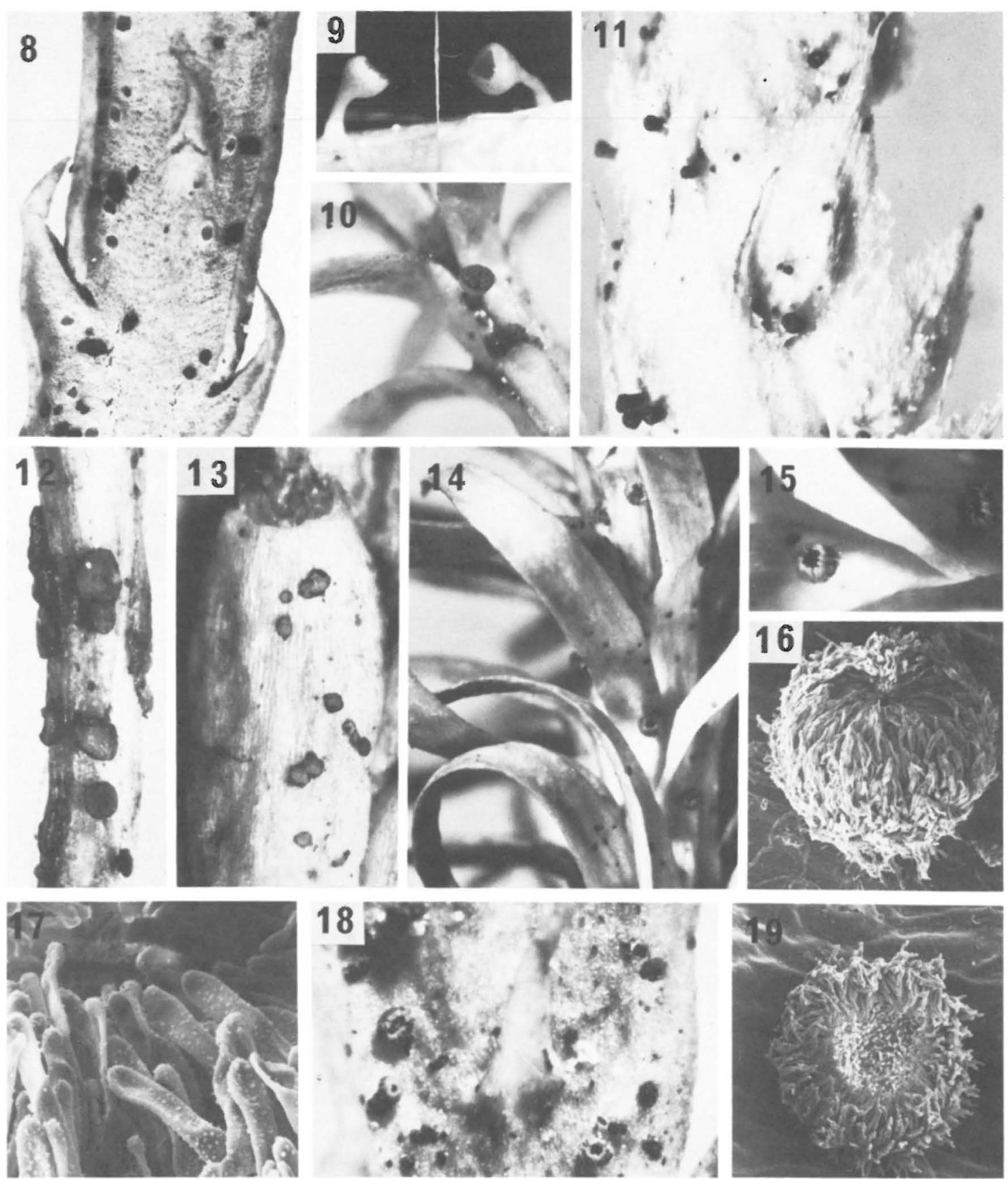

Figs. 8-19 - 8: Cryptodiscus anguillosporus, apothecial openings, $\times 14$ - 9: Cyathicula cyathoidea, apothecia (type collection of Helotium lycopodinum), $\times 32$. - 10: Poculopsis orgensis, apothecium, $\times 12 .-11$ : Cyathicula cyathoidea, very young a pothecia (Holm 474a), $\times$ 16. - 12: Mollisia sp., a pothecia, $\times 16 .-13$ : ?Micropeziza diphasii, apothecia, $\times 32$. 14-17:Dasyscyphus inopinatus (14-16: apothecia, $\times 16, \times 32$ and SEM $\times 150 ; 17$ : hairs, SEM $\times 1100)$. - 18-19: Hyalopeziza rubefaciens, apothecia, $\times 32$ and SEM $\times 250$. 
27.Vlil.1980, 2235e. Folkärna pr. Korskrogen: 19.V1.1979, 1580d; 23.V11.1979, 1822f; 16.X.1980, 2216a. - Angermanland: Ullånger, Håll, 24.X.1980 Moberg. - Torne Lappmark: Jukkasjärvi, Kaisepakte, 28.V1l.1939 Alm \& Smith. Gällivare, Dundret, VII.1930 Lind. Karesuando, 1833 Laestadius.

\section{Phacidina gracilis (Niessl) von Höhnel} - Figs. 1i, 23 von Höhnel, Ber. Deutsch. Bot. Ges. 35:422 (1917). - Phacidium gracile Niessl apud Voss, Österreich. Bot. Zeitschr. 32:357 (1882). - Type: Jugoslavia, Ljubljana (Laibach), $L$. complanatum, Vill.1882 Voss.

Exs.:Rbh., F. eur. 2459 (UPS).

Ascocarps scattered, subcuticular, scutate, (50-) $100-200 \mu \mathrm{m}$ in diam., $50 \mu \mathrm{m}$ high. Shield pseudoparenchymatous, not radiate, at centre $10-15 \mu \mathrm{m}$ thick, composed of c. 5 layers of strongly pigmented cells, at margin consisting of 1 layer of hyaline cells; splitting irregularly at maturity and exposing the pale hymenium. Lateral excipulum c. 0, basal layer weakly developed, composed of $1-2$ layers of very small, globose cells, c. $2 \mu \mathrm{m}$ in diam., with slightly thickened, somewhat referactive walls. Interascal threads present, articulate. Asci broadly clavate, narrowing upwards, c. $25 \times 5-6 \mu \mathrm{m}$, subsessile, with a minute apical ring, c. $1 \mu \mathrm{m}$ in diam., $1+, 8$-spored. Spores rod-like, thickening slightly upwards, c. $7 \times 1 \mu \mathrm{m}$, one-celled, hyaline.

Though the species has a distinctive appearance, the subcuticular ascocarps looking like shining black dots, its true taxonomic positions is a difficult problem, and has been understood in various ways. Originally described as a Phacidium, it was still regarded as such by Rehm (1888). Von Höhnel (1917) ranged it among the Leptopeltidaceae, and Nannfeldt (1932) considered it to be ascolocular. Von Arx and Müller (1954) treated it thoroughly, concluding that it was closely akin to Phacidium. According to them the ascocarps are stromatic with interthecial threads attached above as well as below: "Zwischen Basal- und Deckschicht sind die Zellen hyalin und in senkrechter Richtung fadenförmig gestreckt: nach dem Heranwachsen der Asci lösen sie sich oben los und werden dann zu 'Paraphysen'." We agree with this interpretation: We have studied the ascocarp structure on ultratome sections, $1 \mu \mathrm{m}$ thick, and as far as we can see the interascal theads are not true paraphyses but pseudo-paraphyses; these are outgrowths from the shield, directed downwards, and the shield is the part of the ascocarp that is formed first. But it is another question whether this type of development is found in Phacidium, which rather has true paraphyses. We are not convinced that these genera are related, but we have no better place for Phacidina, which seems to be very isolated.

An anamorph has been attributed to Phacidina gracilis, viz. Ceuthospora lycopodii Lind, by Kendrick $\&$ DiCosmo (1980), on the basis of a vague supposition by von Höhnel (1925). There is no evidence for such a connection, which seems highly improbable.

Phacidina gracilis is very common on L. complanatum and perhaps co-extensive with this plant. It is particularly abundant in the margins of the undersi- de. It is also found on L. alpinum (recorded already by Lind 1934); more surprising is its rather frequent occurrence on $L$. clavatum.

\section{Pyrenomycetes unitunicati Niesslia haglundii Starb.}

- Figs. 1o, 25, 35 Starbäck, Bih. K. Sv. Vet.-Akad. Handl. 14(3:5):9 (1889). Venturia Haglundii (Starb.) Saccardo, Syll. Fung. 9:694 (1891). - Type: Sweden, Östergötland, Simonstorp, $L$. complanatum, E. Haglund (S?).

Exs.: (Petr., F1. Bohem. Mor. 11:1 no. 1246b, intermixed).

This fungus can hardly be distinguished from the plurivorous Niesslia exilis on morphological grounds, nor did Starbäck indicate any differences. But for the time being we prefer to keep it as a separate taxon since it is probably biologically distinct. $N$. haglundii is apparently not plurivorus, as we have found it exclusively on the two members of the subgenus Diphasium, i.e. L. alpinum and L. complanatum. For a description of $N$. exilis, see e.g. Müller and von Arx (1962:576).

$N$. haglundii is similar to Gibbera lycopodii in gross appearance, but can generally be recognized under the binocular by the still more collapsed ascocarps with shorter bristles and without subiculum. Spores $9-11 \times 1.5 \mu \mathrm{m}$, with several distinct oil droplets. The species seems to be fairly common on L. complanatum, particularly on the underside of younger branches. It can also infest L. alpinum: We have found it once on this host, on an old herbarium sheet:

Norway: Finnmark: Varanger, 8.IX.1851 Chr. Sommerfelt (UPS).

\section{Pseudomassaria lycopodina (Karst.) von Arx} - Figs. 1u, 27, 28, 33, 34 von Arx, Beitr. Kryptog.-F1. Schweiz 11(2):686 (1962). Shaerella lycopodina Karsten, F. fenn. exs. 596 (1866). Type: Finland, Mustiala, L. complanatum (UPS, iso).

?Metasphaeria lycopodii (Berk. \& Curt.) Sacc., Syll. 2:183 (1883). - Sphaeria Lycopodii Berkeley \& Curtis, Grevillea 4:155 (1876). - Type: 'U.S.A., New Jersey, on Lycopodium, No. 4686' (K!).

Exs.: Karst., F. Fenn. 569 (UPS). - Lund. \& Nannf., F. suec. 2292 (UPS). - Rbh., F. eur. 1154 ('Gnomonia Niessli') (UPS). - Rehm, Asc. 1392 (UPS) (Roum., F. sel. 4653). Syd., Myc. germ. 582, 1233, 2694 (UPS); Myc. march. 2132 (UPS). - Thüm., myc. univ. 1848 ('Leptosphaeria microsticta') (UPS).

Perithecia \pm thickly scattered, mainly in the upper leafside, immersed, depressed, c. $150 \mu \mathrm{m}$ in diam., with a minute papilla, sometimes slightly clypeate. Peridium often double, consisting of a primary inner wall, fairly rather light brown, c. $5 \mu \mathrm{m}$ thick, composed of $1-2$ layers of strongly compressed cells, rather large, up to $15 \mu \mathrm{m}$, and a secondary outer wall, about as thick, composed of coarse, interwoven darkening hyphae. Asci numerous, \pm cylindrical, $60-80 \times 8-10$ $\mu \mathrm{m}$ with a minute apical ring, $1+, 8$-spored. Spores rather variable in size and shape, \pm 'banana-shaped' $14-24 \times$ $4-5 \mu \mathrm{m}$, hyaline with large \pm diffuse oil drops, finally with a septum near the base (sometimes lacking?); nuclei often stained by Cotton Blue.

In $L$. annotinum and L. complanatum.

Perhaps the most common of all the microfungi on 

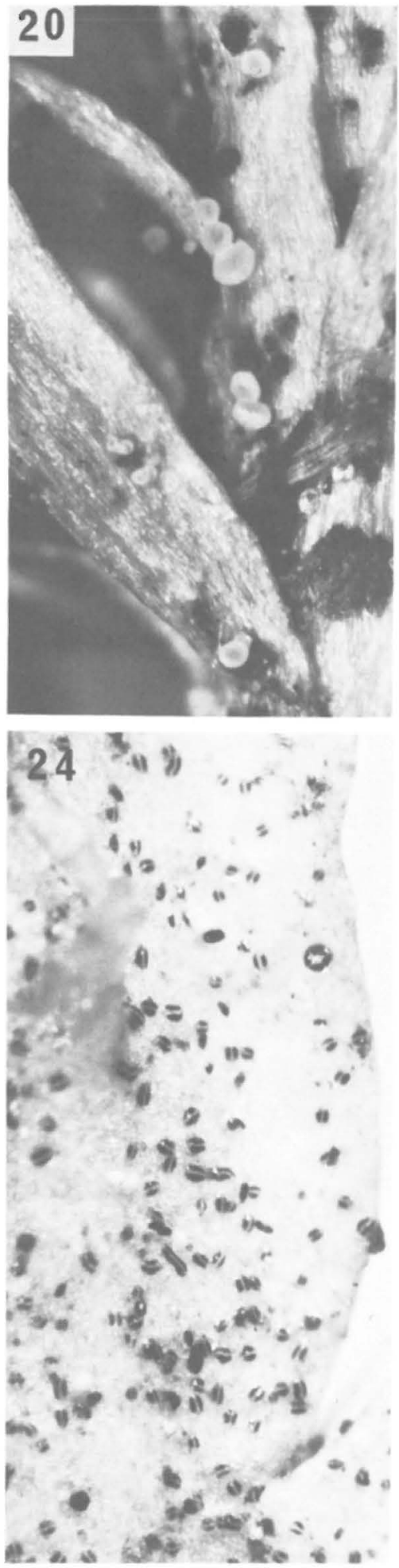
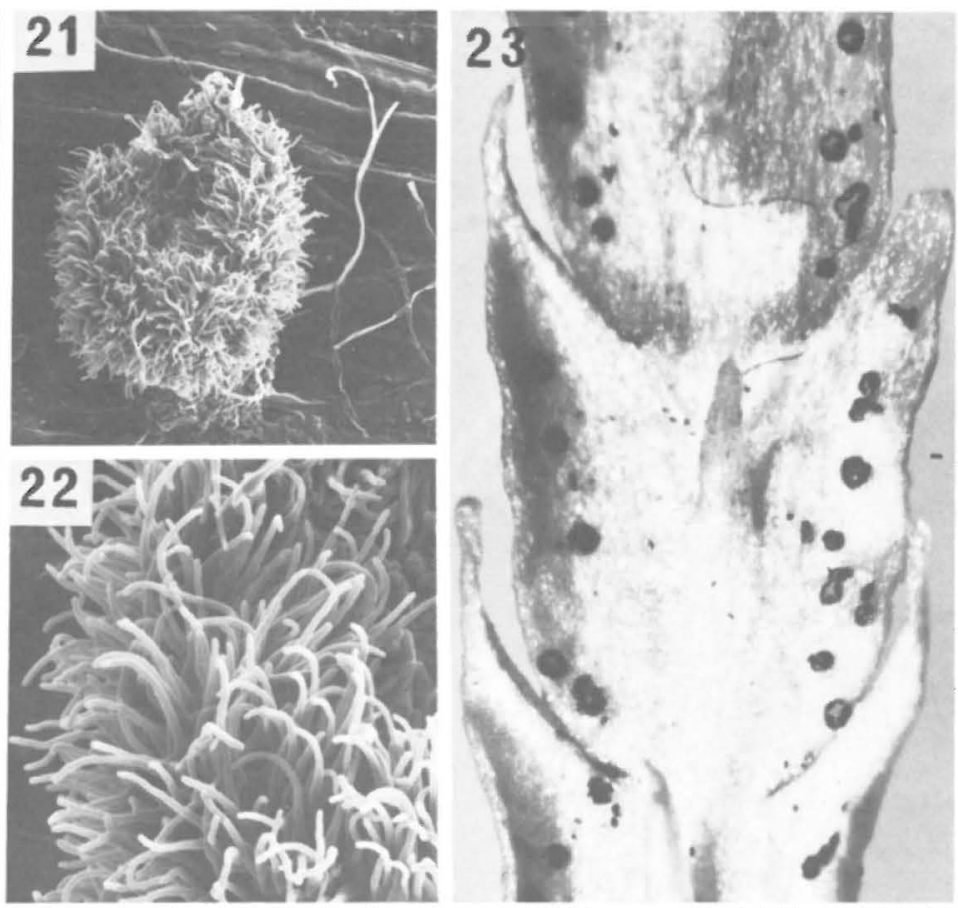

Figs. 20-24. - 20-22: Hyalopeziza pani $(20-21$ : apothecia, $\times 32$ and SEM $\times$ 250; 22: apothecial hairs, SEM $\times 900)$. -23 : Phacidina gracilis, apothecia, $X$ 16. - 24: Pseudopeltis perminuta, apothecia, $\times 32$.

Lycopodium, and at least sometimes a true parasite, infesting green leaves (e.g. in Lundell \& Nannf., F. suec. no. 2292). It is noteworthy because of the peculiar peridium structure (first pointed out by Barr 1964): the perithecial wall often consists of two clearly different layers: apparently the outer layer is of ten lacking (the reverse condition perhaps sometimes prevails?). The outer wall layer may develop into a slight clypeus.

The species has been described several times; a detailed synonymy was published by Barr (1964). We can add one further probable synonym, viz. Metasphaeria lycopodii. There are two packets at $\mathrm{K}$ under his name, very probably parts of the same collection: 1) Ex herb. Berkeley no. 4686 - a very small specimen with empty perithecia. 2) A fragment from herb. Ravenel, with the annotated locality 'New Jersey, Laning' and with plenty of perithecia of Pseudomassaria lycopodina. The host in both packets is $L$. complanatum coll. We would have no hesitation in identifying Sphaeria Lycopodii with the Pseudomassaria, had not Berkeley stated in the original (poor) description that the spores are 'biseptate'. However, we are inclined to belive that this is an error for 'bicellular'. As far as we know, no other find of Sphaeria lycopodii has ever been recorded.

Opinions vary regarding the true taxonomic position of the species. It has repeatedly been regarded as 
sphaerellaceous, even by as late an author as Kirschstein (1938), though Auerswald (1869) had a better idea of it, many years earlier, referring it to Gnomonia. We have some hesitation in following the current practice of placing it in Pseudomassaria. It is obviously related to this genus but it is hardly closely akin to the type species, $P$. chondrospora (Ces.) Jacz., on twigs of Tilia. On the other hand, it seems very close to some Physalospora species on Ericaceae, like $P$. clarae-bonae (Speg.) Theiss. and P. empetri Rostr. The present circumscription of Pseudomassaria is probably rather schematic.

$P$. lycopodina is common and generally abundant on $L$. annotinum and $L$. complanatum, but curiously enough not found on L. clavatum. We have seen Swedish material from the provinces of Skåne, Östergötland, Uppland, Dalarna, and Hälsingland, and one collection from Finland, Tavastland.

\section{Pyrenomycetes bitunicati}

\section{Gibbera lycopodii L. \& K. Holm sp.nova}

- Figs. 1k, 29, 30, 40

Ascocarpia superficialia, globosa vel in sicco depressa, 80 $-100 \mu \mathrm{m}$ diam., sursum setulis brunneis rigidis non septatis ad $175 \times 5 \mu \mathrm{m}$, basi hyphis numerosis \pm brunneis. Peridium e textura angulari, cellulis ad $12 \mu \mathrm{m}$. Asci subsaccati, 45-55 $\times 12-15 \mu \mathrm{m}$, brevissime stipitati, octospori. Sporae $12-15(-18) \times 4-5 \mu \mathrm{m}$, dilute virides, postremo pallido brunneae, cellula superiore saepe paullo latiore. Ad folia sicca vel viva Lycopodii spp.

Typus: Suecia, Härjedalen, par. Tännäs, Fjällnäs, c. 800 m, L. annotinum, 26.VI.1975 Holm 599b (UPS, holo).

This species seems well characterized by the very long bristles and the often profuse subiculum. It is a Protoventuria in Barr's classification. Besides the type we have five collections:

Sweden. Dalarna: Idre, pr. Mt Nipfjället, L. annotinum, 26.VI.1975, 598a. - Härjedalen. Tännäs. Mt Hamrafjället, r. alp., L. alpinum, 27.VI.1975, 620c.-Lycksele Lappmark. Tärna, Mt Ryfjället, L. alpinum, 27.VII.1928 Lindström.

Norway. Nordland: Örtfjellmoen, L. annotinum, 11.IX.1976 Lundqvist 10518a.

Iceland. Eyjafjarđ̛arsýsla, Olafsfjarđ̆armúli, L. alpinum. 1.VIII.1971, 13b-71.

\section{Venturia lycopodii L. \& K. Holm sp.nova}

$$
\text { - Figs. 1v, 32, 44, } 45
$$

Typus: Suecia, pr. Gävle, in silva Tolfforsskogen, L. annotinum, 15. VIII.1950 J. A. Nannfeldt 11357b (UPS, holo).

Exs: Petr., F1.Bohem. Mor, exs. II:1 no. 1246 ('Mycosphaerella lycopodina') (S!).

Acocarpia solitaria, sparsa, amphigena, immersa, papilla minuta erumpentia, fere globosa, vulgo $50-80 \mu \mathrm{m}$ diam., sat pallide brunnea autem circa ostiolum plerumque annulatim nigra, interdum setis paucis fuscis ad $30 \mu \mathrm{m}$ longis apica instructa. Peridium tenue, c. $6 \mu \mathrm{m}$ latum, e textura angulari, cellulis vulgo $5-10 \mu \mathrm{m}$, circa ostiolum minoribus. Asci sat numerosi, subsaccati, sessilia, 24-30 $\times 5-6 \mu \mathrm{m}$, octospori. Sporae oblongae, $7-12 \times 2-2.5 \mu \mathrm{m}$, terminaliter obtusae, medio septatae, hyalinae, indistinctae guttulatae. Filamenta interthecialia mature dissolutae. In foliis caulibusque siccis Lycopodii annotini.

This species has puzzled us a great deal, but with some experience it can generally be recognized by sight in the binocular; it is fairly well distinguished by the small ascocarps, which when moist are light brown except for a dark annular zone around the ostiole. It is often intermixed with other pyrenomycetes and can easily be confused with solitary fruit bodies of Mycosphaerella lycopodii-annotini. Moreover, it greatly resembles a Mycosphaerella in the hyaline spores, and it should be noted that apical setae are mostly lacking. However, the presence of interthecial threads at a young stage clearly indicates Venturia. Though certainly a common fungus, it has hitherto been almost completely overlooked. The sole exception may be Petrak's abovementioned exsiccata. It is labelled 'Mycosphaerella lycopodina (Karst.)', which name apparently refers to Venturia lycopodii, which is fairly abundant in this sample. Petrak certainly did not have the true Karstenian fungus in mind (i.e. Pseudomassaria lycopodina), as he knew that species under another name, viz. Pseudapiospora necans (Rehm) Petr. The exsiccata in question merits some further comments. The host is stated in sched. to be $I$. clavatum, but is actually $L$. annotinum, at least in the copy at S. Still more confusion was introduced by Petrak (1920:12) when he reported that the host of no. 1246 is L. complanatum! In fact, there is also a no. $1246 \mathrm{~b}$, likewise labelled ' $M$. lycopodina (Karst.)', the host of which is L. complanatum; the copy at $\mathrm{S}$ of this b-collection contains no fungus but Phacidina gracilis. Beside the type we can cite the following collections:

Sweden. Bohuslän: Lindome, Greggered, 8.IX.1979 and 1.I.1981 Bengtsson. - Uppland: Uppsala-Näs, pr. Dalkarlskärret, 4.X.1980 Stendahl. Väddö, 2.X.1980 Stendahl. Dalarna: Sundborn, Övertjärn, 18.V11.1974, 310e. Garpenberg, 29.VlIi.1974, 353b. Folkärna, pr. Korskrogen, 23.VII.1979, 1823c. - Hälsingland: Segersta, Digerberget, 26. VII.1963 Nannfeldt 17977a.

Norway. Nordland: Örtfjellmoen, 11.1X.1976 Lundqvist $10518 \mathrm{~b}$.

Iceland. Barđastranđarsýsla, pr. Vatnsfjörđur, 23. VII.1962 Nannfeldt $17576 \mathrm{e}$

Czechoslovakia. Moravia, Weisskirchen, 27.VIll.1914 Petrak $(\mathrm{S})$.

Massarina chamaecyparissi (Rehm) L. \& K. Holm comb.nova

- Figs. 11, 36

Didymella Chamaecyparissi Rehm in Voss, Verhandl. Zool.Bot. Ges. Wien 34:10 (1884). - Type: Jugoslavia, Ljubljana, L. complanatum ssp. chamaecyparissus, VIII.1883 Voss, (S!).

Metasphaeria lycopodina Petrak, Ann. Mycol. 32:426 (1934). - Type: Czechoslovakia, Weisskirchen, L. annotinum, IX.1928 (n.v.).

Exs:: Petr., F1. Bohem. Mor. 11:1 no. 2485 (S) - Syd., Myc. germ. 1092 (S, UPS).

Ascocarps mostly epiphyllous, \pm densely scattered, immersed, depressed, $150-200 \mu \mathrm{m}$ in diam., epapillate, with a thin peridium, light brown when young, darkening with age. Asci clavate, 55-60(-65) × 8-10 $\mu \mathrm{m}, 8$-spored. Spores fusiform, hyaline when young with numerous very distinct oil globules, bicellular, somewhat inflated above the septum, 

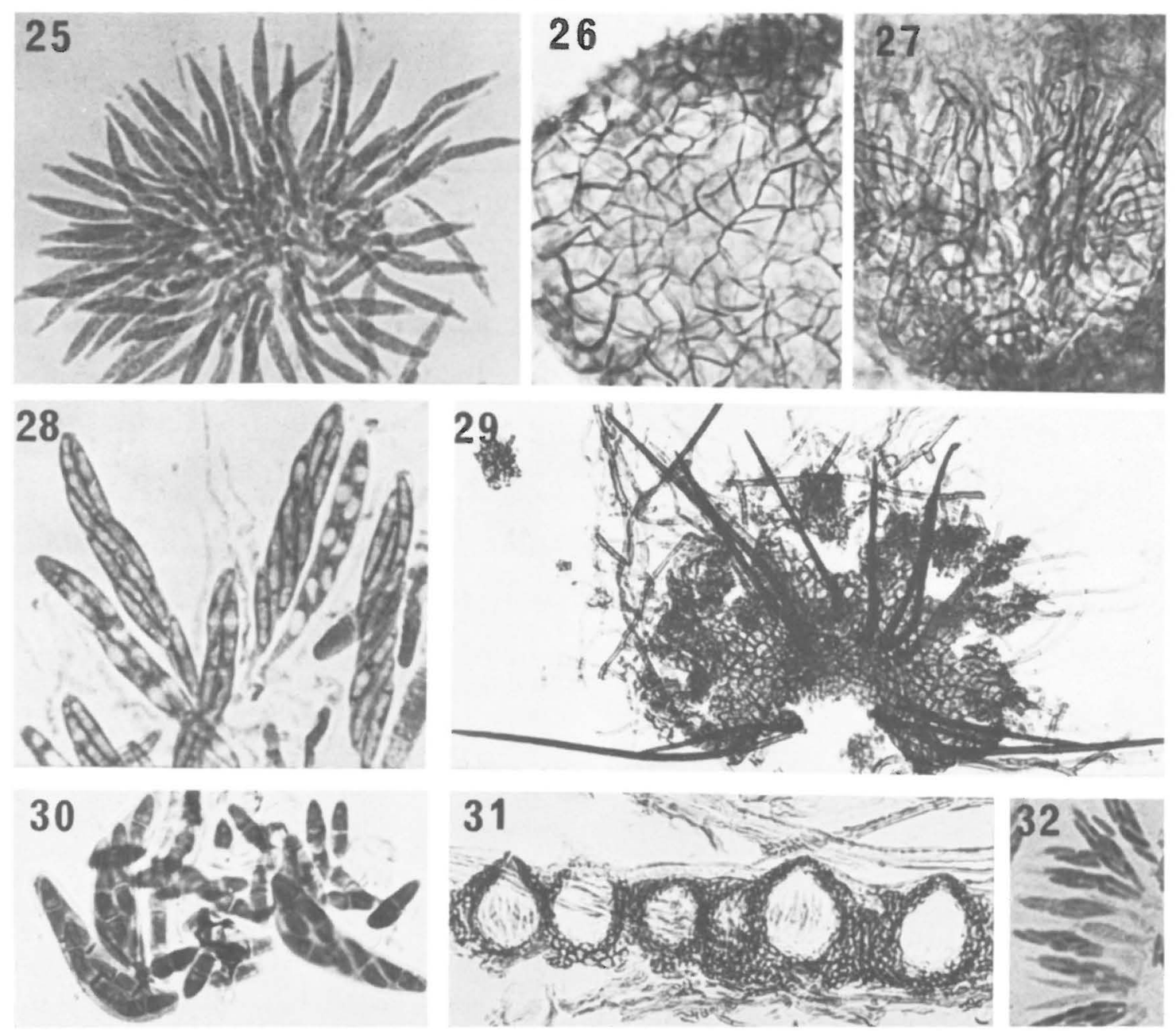

Figs. 25-32. - 25: Niesslia haglundii, asc1 in Lactic Blue, $\times$ 530. - 26-28: Pseudomassaria lycopodina (26: texture of primary perithecial wall; 27: texture of outer wall; 28: asci with spores in Lactic Blue), X 530. - 29-30: Gibbera lycopodii (29: crushed ascocarp with setae and subiculum, $\times 210 ; 30$ : asci and spores in Lactic Blue, $\times 530) .-31$ : Mycosphaerella lycopodii-annoti$n i$, section of grouped ascocarps, asci coloured with Lactic Blue, $\times 210 .-32$ : Venturia lycopodina, asci in Lactic Blue, $\times 530$.

$23-25 \times 4 \mu \mathrm{m}$; when maturing apparently shrinkıng somewhat in size, $18-20 \times 3-4 \mu \mathrm{m}$, the wall turning brownish and verruculose. 1 or 2 additional septa are sometimes formed.

Petrak (1934) published a detailed description, but he obviously never observed fully mature spores - as a matter of fact they are only rarely seen, as is often the case with the so-called Metasphaeriae. It is thus quite comprehensible that Rehm mistook the fungus for a Didymella. It seems to fit in well in Massarina and the spores recall e.g. M. corticola (Fckl.) L. Holm Its gross appearance is suggestive of Pseudomassaria lycopodina, and the two species can hardly be safely differentiated without the compound microscope.

Massarina chamaecyparissi is no common species and it has been but little noticed. It is not mentioned in Corbaz' (1956) study of Didymella. Besides the type and the exsiccata cited we have seen the following material:

Sweden. Uppland: Bälinge, pr. Piparröningen, L. annotinum, 13.X.1968 Nannfeldt 20464. Dalby, pr. Ostbergstorpet, L. clavatum, 12.VII.1979, 1791a. Tunaskog, L. complanatum, 30.X.1980, 2264b. Ekeby, L. annotinum, 10.VII.1974, 266a. Forsmark, Granskär, L. annotinum, 26.IX.1962 Eriksson 1757 (UME 26798). - Västmanland, Västerfärnebo, $L$. complanatum, 20.1X.1980 Rosén. - Dalarna: Garpenberg, L. annotinum, 29.VIIll.1974, 348a. St.Kopparberg, Mt Krokforsberget, L. complanatum, 6.VIIl.1974, 326d.

Jugoslavia. Ljubljana, L. complanatum spp. cham., Vll.1886 Voss (S).

Phaeosphaeria fuckelii (Niessl) L. Holm L. Holm, Symb. Bot. Upsal. 14(3):123 (1957). - Fig. 1p 
sphaeria Fuckelii Niessl apud Voss, Oesterr. Bot. Zeitschr. 32:357 (1882). - Type: Jugoslavia, Ljubljana (Laibach), Calamagrostis arundinacea, 13.Vll1.1882 Voss (S!).

Leptosphaeria lycopodiicola Peck, Ann. Rep. New York State Mus. 38:105 (1885). - Type: USA, N. Y., Adirondack Mts, L. clavatum, Peck (NYS!).

Exs.: vide L. Holm 1957:123.

This is a common species on various grasses, but it is also found on other hosts, especially on Equisetum. L. Holm (1957) recorded it on Lycopodium clavatum, on the basis of the type collection of Leptosphaeria lycopodiicola, which he identified with $P$. fuckelii. Generally this species has 5-septate spores according to the formula 3-1-2 (cf. L. Holm 1957:92, 123), but considerable variation in spore septation often occurs, as O. Eriksson (1967b) has demonstrated. Possibly $P$. fuckelii is a collective species. As a matter of fact, the cited type of Leptosphaeria lycopodiicola has predominantly 6 -septate spores, of the formula $4-1-2$. It is truly remarkable that the same condition prevails in a second collection on Lycopodium, viz. Holm 348j, cf. below. This material is not too scanty, and there is possibly a particular form of the fuckelii complex infesting Lycopodium.

Sweden. Dalarna: Garpenberg, L. annotinum, 29.VI11.1974 Holm 348j.

\section{Phaeosphaeria herpotrichoides (De Not.) L. Holm} - Fig. 1q

This apparently 'collective' species is widespread and common on numerous grasses; its many forms have been treated in detail by O. Eriksson (1967b). It is known to occur on other monocots, too, particularly on Carex, but has not been reported earlier on Lycopodium. We have found it once, in the spikes of $L$. clavatum, on an old herbarium sheet, vide infra. The infection is heavy, recalling Ph. lycopodina. Dr. Eriksson has kindly examined the fungus, and informs us (in litt.) that it perfectly matches his Form 5a (Eriksson 1967b:423), which is very frequent in the Scandinavian mountains.

Norway. Finnmark: Karasjokk, Mt Dafteroaive, L. clavatum v. lagopus, sine dato, J.M. Norman.

\section{Phaeosphaeria lycopodina (Mont.) Hedjaroude} - Figs. 1s, 43

Hedjaroude, Sydowia 22:78 (1969). - Sphaeria lycopodina Montagne, Ann. Sci. Nat. Bot.(ser. 3) 12:313 (1849). - Leptosphaeria lycopodina (Mont.) Sacc., Syll. 2:81 (1883). Type: Canada, Newfoundland, L. annotinum, La Pylaie (PC!).

\section{Exs.: vide L. Holm (1957:70)}

The most conspicuous of all the lycopodiicolous fungi, distinguished by its peculiar biology: it is confined to the spikes, which are discoloured and finally almost blackened. The ascocarps are formed in the bracts, and are surrounded by a rather profuse tomentum. Detailed descriptions and a full synonymy have been published by L. Holm (1957) and Hedjaroude (1969). The generic affinity has been rather doubtful; the assignment to Phaeosphaeria is reasonable, and at least nothing argues against it.

This common and widespread species has been distributed in several exsiccata, which were listed by L. Holm (1957). We have seen it on Lycopodium alpinum, L. annotinum, and L. clavatum.

Phaeosphaeria marciensis (Peck) L. \& K. Holm comb. nova

- Figs. 1r, 42

Sphaeria Marciensis Peck, Ann. Rep. New York State Mus. 31:51 (1879). - Leptosphaeria marcyensis (Peck) Saccardo, Syll. Fung. 2:80 (1883). - Type: U. S. A., New York, Mt Marcy, L. annotinum, VIII. 1877 Peck (NYS!).

One of the most common pyrenomycetes on $L$. annotinum. The ascocarps are generally scattered, immersed in the leaves, particularly in the margins, and can as a rule be identified by the rather prominent papilla. We have seen one collection from Swedish Lapland, though, with caulicolous, crowded ascocarps. For a detailed description, the reader is referred to Holm (1957), and Lucas and Webster (1967). The latter authors cultured the species and obtained a Diplodina stage. It can be mentioned that we have occasionally come across a Diplodina on L. annotinum.

Ph. marciensis seems to be comparatively rare on other hosts than L. annotinum and the few finds of that sort are listed below. It is remarkable that we have seen it only once on $L$. clavatum; Lucas and Webster (1967) reported a British find on this plant.

On L. clavatum: Sweden. Uppland: Åland par., Rövarkulan, 22.VIl1.1979, $1854 \mathrm{f}$.

On 1. alpinum: Sweden. Pite Lappmark: Arvidsjaur, Vittjokk, 12.Vill. 1943 Nannfeldt 6974b.

On L. selago: Sweden. Härjedalen: Vemdalen, Mt Högfjället, 28.VIll.1915 Nordström. Finland. Kúusamo: Korojoki, 16.V1.1911, Pl. Finl. exs. 1014.

\section{Pleospora islandica Johanson}

Johanson, Öfvers. K. Sv. Vet.-Akad. Förhandl. 1884(9):170 (1884). - Type: Iceland, Hólar, Poa glauca, 22.VIl.1883 H. Strömfeldt (UPS!).

?Pleospora lycopodiicola Lind, K. Danske Vid. Selsk., Biol. Meddel. 11 (2):34 (1934). - Type: not indicated.

Pleospora islandica is very common on grasses in northern regions, and is also known from Carex. It is charcterized well by the spores with light end cells; there are 7 transverse and 1 or 2 longitudinal septa. For a full description, the reader is referred to Eriksson (1967a).

Figs. 33-41. Ascocarps in surface view. - 33-34: Pseudomassaria lycopodina (34: clypeate ascocarps), both $\times 16$. -35 : Niesslia haglundii, $\times 32$. - 36: Massarina chamaecyparissi, $\times 8 .-37-38$ : Mycosphaerella lycopodii-annotini, $\times 16$ and $\times 32$. - 39: Mycosphaerella lycopodii, $\times 16$. - 40: Gibbera lycopodii, $\times 32$. - Mycosphaerella lycopodii on sphorophylls (type collection), $\times 16$. 

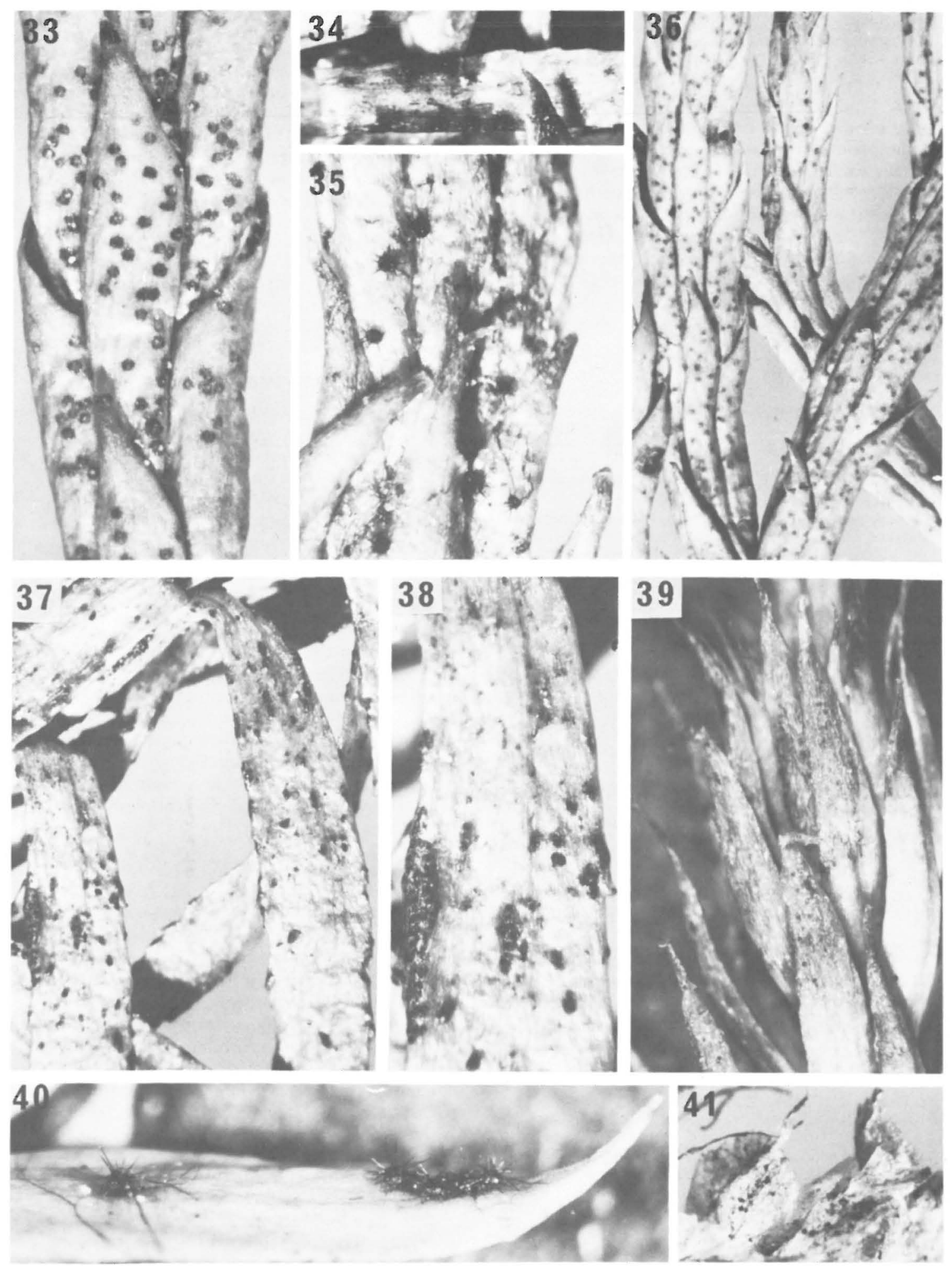
It appears that the species can also (incidentally?) infest Lycopodium. In two collections, mentioned below, we have found a sparsely occuring fungus, which agrees morphologically with $P$. islandica. $P$. lycopodiicola Lind is very probably the same fungus. Lind based his description on 3 collections from Swedish Lapland, on Lycopodium alpinum, L. annotinum, and L. clavatum, respectively. (He reported it from Denmark, too.) Wehmeyer (1961:85) examined one of the syntypes (Sweden, Karesuando?, L. annotinum, Laestadius, C) and found a Pleospora, apparently $P$. lycopodiicola. He emphasized that it was close to ' $P$. heleocharidis' ( $=P$. islandica), though possibly representing a somewhat deviating form.

Sweden. Lycksele Lappmark: Tärna, N. Storfjället, 800 m.s.m., 19.IX. 1953 Norrman.

Finland. Lapponia kemensis: Muonio, Kätkäsuvanto, L. annotinum, 27.VIII.1915 Montell.

\section{Mycosphaerella lycopodii (Peck) House}

- Figs. 1m, 39, 41

House, Bull. New York State Mus. 233-234:28 (1921). Sphaerella Lycopodii Peck, Rep. New York State Mus. 39:51 (1886). - Type: U. S .A., N. Y., Adirondack Mts., Essex County, in spikes of $L$. clavatum, Peck (NYS!).

Ascocarps \pm crowded, globose, $40-80 \mu \mathrm{m}$, immersed erumpent, seated on a generally profuse, subcuticular mycelium of coarse, dark hyphae. Asci pyriform - saccate, $20-30 \times 8-12 \mu \mathrm{m}, 8$-spored. Spores obovate-oblong, hyaline, straight, with a median or often sligthly supramedian septum and small indistinct guttules, $8-12(-14) \times$ $2.5-4(-5) \mu \mathrm{m}$.

In dead and dying leaves and sporophylls of Lycopodium spp.

To the slight extent that this species has been noted so far, it has been recorded from sporophylls only. However, a similar and obviously indentical fungus grows in vegetative leaves, particularly in the apices. As pointed out by Barr (1959:18), M. lycopodii 'is closely releated to $M$. minor and is distinguished chiefly by the substrate'. It is perhaps best regarded as a biological 'race' of $M$. minor (Karst.) Joh., specialized to Lycopodium. It seems to be weakly parasitic, often being found in moribund leaves. These are characteristically discoloured: they look grayish owing to the raised cuticle, and are darkened by the mycelium and ascocarps.

$M$. lycopodii is probably a northern and alpine-subalpine species. It is very common in the Scandinavian mountains, especially in vegetative leaves of $L$. alpinum, L. annotinum, L. clavatum and L. selago.

\section{Mycosphaerella lycopodii-annotini Petr.}

$$
\text { - Figs. 1n, 31, 37, } 38
$$

Petrak, Krypt. Forsch. 2:167 (1931). - Type: Germany, Schwaben, Seilachmoor, L. annotinum, 23.VI.1928 Ade (n.v.).

?Mycosphaerella lycopodiicola Moesz \& Smarods, Bot. Közlem. 34:60 (1937). - Type: Latvia, pr. Riga, L. annotinum (n.v.).

Ascocarps immersed, mainly in the upper leaf side and in the margins, subglobose, $50-80 \mu \mathrm{m}$, with a short but distinct papilla, solitary, or generally crowded, a few to many, in dense groups. Asci numerous in a fascicle, subsaccate. sessile, mostly $30-35 \times 7-8 \mu \mathrm{m}, 8$-spored. Spores fusiform with \pm pointed ends and a median septum, 10-12(-15) $\times$ $2.5-3 \mu \mathrm{m}$, hyaline with indistinct guttules.

A conspicuous fungus, distinguished by the crowded ascocarps, which are either immediately adjacent to each other or united by intermediate stromatic tissue. Solitary ascocarps are also \pm surrounded by such tissue, because of which they look very dark. A lengthy description was given by Petrak (1931). It is a common species but so far known from Lycopodium annotinum only. $M$. lycopodiicola is very probably a synonym.

The species resembles $M$. juniperina (Ell.) Tomilin (cf. Holm \& Holm 1977) and they are certainly related.

\section{Review and conclusions}

A survey of the present fungi and their frequency on the different hosts is given in Table 1. In spite of its modest size, the material seems sufficient to allow of some inferences. It is above all obvious that the lycopods differ considerably inter se with regard to their mycoflora. It is noteworthy that none of the fungi is common to all five hosts. Mycosphaerella lycopodii is the most general of them, missing only on L. complanatum, and this absence may of course merely be due to the limited material. But polyphagy is certainly not the rule among these fungi.

L. complanatum deserves an honourable mention as particularly mycophilous, with half a dozen species of its own. A peculiar fungal community is found on this plant, consisting mainly of some strongly reduced superficial or subcuticular discomycetes, like Hyalopeziza rubefaciens, Micropeziza? diphasii, Phacidina gracilis, and Pseudopeltis perminuta. Niesslia haglundii also belongs to this society. Not unexpectedly, a certain resemblance can be found to the mycoflora on $L$. alpinum (Cryptodiscus spp., Phacidina gracilis, Niesslia haglundii). More surprising is the indubitable difference between $L$. annotinum and L. clavatum. It is remarkable that species like Mycosphaerella lycopodiiannotini and Venturia lycopodina, which are very frequent on L. annotinum, seem to be rare on $L$. clavatum. This difference can hardly be due only to the higher number of annotium samples.

A remarkable phenomenon is the predilection for sporophylls manifest in some species. This particular substrate is obviously rich in nutrients. The very common Phaeosphaeria lycopodina is evidently restricted to the spikes; so are, at least in the few samples at hand, Cyathicula cyathoidea and Phaeosphaeria herpotrichoides. Mycosphaerella lycopodii is noteworthy as occuring in sporophylls as well as in vegetative leaves.

Our main impressions of this mycoflora can be summarized in two points: 1) It is highly specific, i.e. 

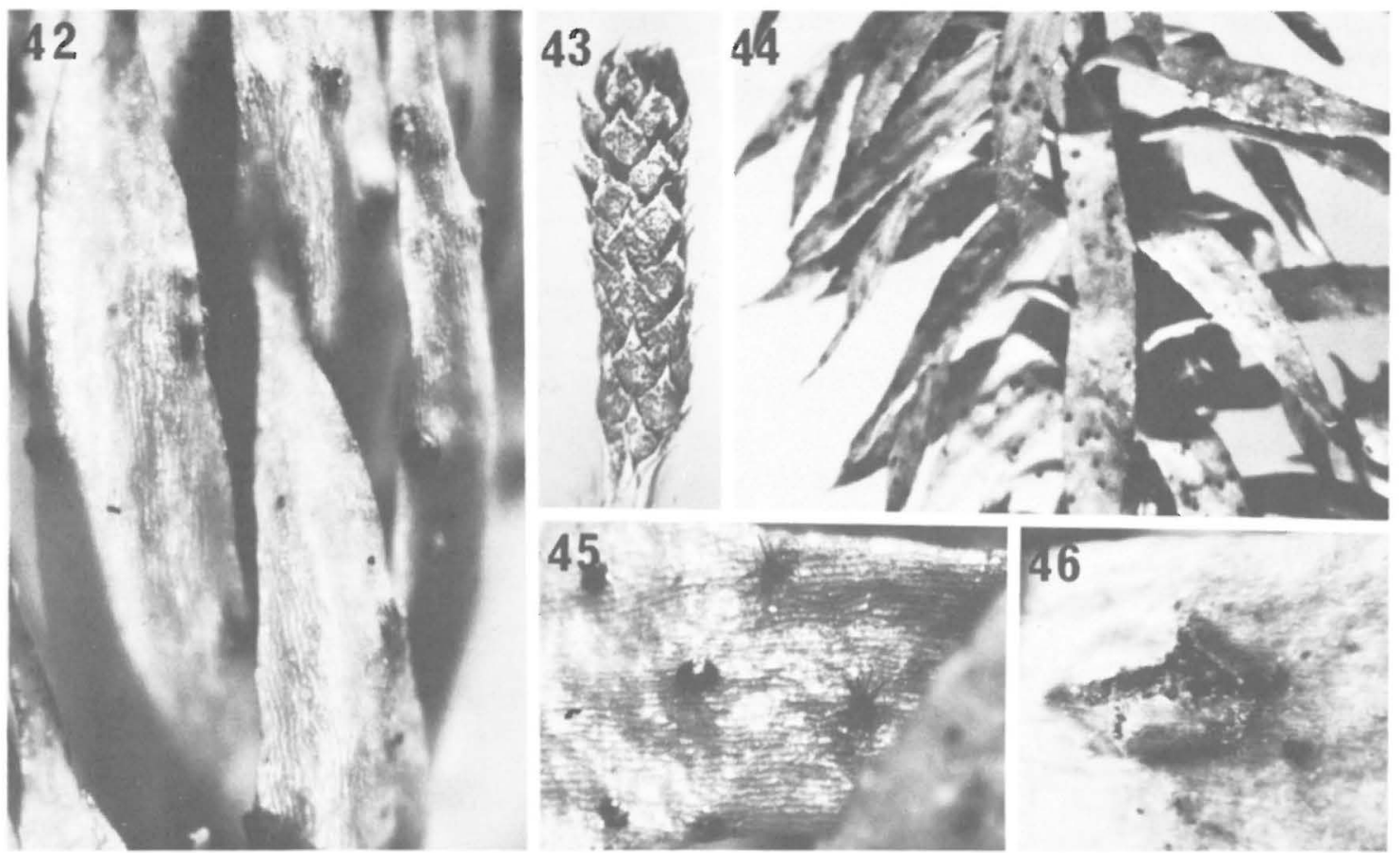

Figs. 42-46. Fruit bodies in surface view -42 : Phaeosphaeria marcyensis, $\times 32,43$ : Phaeosphaeria lycopodina, $\times 3$. 44-45: Venturia lycopodina (45: glabrous and setose ascocarps), $\times 8$ and $\times 32$. -46 : Ceuthospora lycopodii, $\times 32$.

Table 1. Number of finds on the different hosts (included are also some finds which are not listed in the text as the material was too scanty to preserve).

Discomycetes

annotinum clavatum

Cryptodiscus anguillosporus

Cryptodiscus sp.

Cyathicula cyathoidea

Poculopsis ogrensis

Mollisia sp.

Micropeziza? diphasii

Dasyscyphus inopinatus

Hamacanthoscypha laricionis

Hyalopeziza rubefaciens

H. pani

Phacidina gracilis

Pseudopeltis perminuta

Pyrenomycetes

Niesslia haglundii

Pseudomassaria lycopodina

Gibbera lycopodii

Venturia lycopodina

Massarina chamaecyparissi

Phaeosphaeria fuckelii

$P$. herpotrichoides

P. lycopodina

P. marciensis

Pleospora islandica

Mycosphaerella lycopodii

M. lycopodil-annotini

Deuteromycetes

Ceuthospora lycopodii
10

1

30

12

6

1

28

17

1
4

25

6
6

\section{Lycopodium \\ complanatum}

alpinum

selago
9

12

4

13

14

11

5

10
1

1

3

\section{1}

5 
the large majority of these fungi are evidently confined to Lycopodium. 2) It is not a radically different flora - most of these species have close relatives on phanerogamous hosts. In some cases direct connections can be traced, e.g. between Mycosphaerella lycopodii-annotini and M. juniperina, and between Pseudomassaria lycopodina and Physalospora spp. on Ericaceae. It is a striking fact that the host plants involved - Lycopodium, Juniperus, Vaccinium, and Empetrum - have a similar xerophytic leaf structure and inhabit the same biotopes.

Two monotypic genera, Poculopsis and Phacidina, are confined to Lycopodium. Poculopsis ogrensis is closely akin to Chloroscypha sabinae on Juniperus and to Phaengellina empetri, on crowberry, thus following the same pattern as the species just mentioned. Phacidina gracilis, on the other hand, is taxonomically isolated in contrast to all the other species treated here, but it is obviously a strongly reduced form.

lt is no exaggeration to say that the mycoflora on Lycopodium, as represented in Scandinavia, gives the impression of being fairly modern, derived from rather recent colonizers, which took the leap from other plants of the same community, not relatives but neighbours.

There are, as far as known, no primitive fungi on Lycopodium - perhaps the Ascomycetes did not yet exist at the time of the major lycopod evolution.

Acknowledgements. Our thanks are due to the curators of the herbaria cited which have kindly sent us material on loan. Were are also much indebted to Mrs Ulla-Britt Sahlström and $\mathrm{Mr}$ Mattias Iwarsson for skilful technical assistance.

\section{References}

von Arx, J.A. \& Müller, E. 1954: Die Gattungen der amerosporen Pyrenomyceten. - Beitr. Krypt.-F1. Schweiz $11(1): 1-434$.

Auenswald, B. 1869: Pyrenomycetes. - In: W. Gonnermann \& L. Rabenhorst, Mycol. Eur. 5-6. Dresden.

Barr, M. 1959: Northern Pyrenomycetes 1. - Contr. Inst. Bot. Univ. Montréal 73:1-101.

- 1964: The genus Pseudomassaria in North America. Mycologia 56:841-862.

Corbaz, R. 1956: Recherches sur le genre Didymella Sacc. Phytopath. Zeitschr. 28:375-414.
Dennis, R.W.G. 1964: Remarks on the genus Hymenoscyphus S.F. Gray ... - Persoonia 3:29-80.

Eriksson, O. 1967a: On graminicolous pyrenomycetes from Fennoscandia 1. Dictyosporous species. - Ark. Bot. (Ser. 2) 6(8):339-379.

- 1967b: On graminicolous pyrenomycetes from Fennoscandia 2. Phragmosporous and scolecosporous species. - Ark. Bot. (Ser. 2) 6(9):381-440.

Hedjaroude, G.A. 1968: Etudes taxonomiques sur les Phaeosphaeria Miyake et leurs formes voisines (Ascomycetes). - Sydowia 22:57-107.

von Höhnel, F. 1917: System der Phacidiales v.H. - Ber. Deutsch. Bot. Ges. 35:416-422.

- 1925: Über die Gattung Ceuthospora Fr. - Mitt. Bot. Inst. Techn. Hochschule Wien 2:99-109.

Holm, L. 1957 Etudes taxonomiques sur les Pléosporacées. - Symb. Bot. Upsal. 14(3):1-188.

Holm, K. \& Holm, L. 1977: Nordic junipericolus Ascomycetes. - Symb. Bot. Upsal. 21(3):1-70.

Holm, L. \& Holm, K. 1978: Some pteridicolous Ascomycetes. - Bot. Not. 131: 97-115.

Kendrick, B. \& DiCosmo, F. 1979: Teleomorph-anamorph connections in Ascomycetes. - ln: Kendrick, B. (ed.): The whole fungus 1:283-410.

Kirschstein, W. 1938: Sphaerellaceae. - Krypt.F1. Mark Brandenburg 7(3):305-448.

Korf, R.P. \& Kohn, L.M. 1980: Revisionary studies in the Hyaloscypheae 1. On genera with 'glassy' hairs. - Mycotaxon 10(2):503-512.

Le Breton, A. \& Malbranche, A. 1884: Excursions cryptogamiques. - Bull. Soc. Amis Sci. Nat. Rouen (Ser. 2)

Lind, J. 1934: Studies on the geographical distribution of arctic circumpolar Micromycetes. - Kongl. Danske Videnskab. Selskab Biol. Meddel. 11(2):1-152.

Lucas, M.T. \& Webster, J. 1967: Conidial states of British species of Leptosphaeria. - Trans. Brit. Mycol. Soc. $50(1): 85-121$.

Müller, E. \& von Arx, J.A. 1962: Die Gattungen der didymosporen Pyrenomyceten. - Beitr. Krypt.-F1. Schweiz 11(2):1-922.

Nannfeldt, J.A. 1932: Studien über die Morphologie und Systematik der nicht-lichenisierten inoperculaten Discomyceten. - Nova Acta R. Soc. Scient. Upsal. (Ser. 4) 8(2): $1-368$.

- 1976: Micropeziza Fuck. and Scutomollisia Nannf. nov. gen. (Discomycetes Inoperculati). - Bot. Not. 129:323-340.

Petrak, F. 1920: Der mykologische Nachlass Joseph Jahn's, ein Beitrag zur Pilzflora des Egerlandes. - Ann. Mycol. 18:105-135.

- 1934: Mykologische Notizen 12. - Ann. Mycol. $32: 317-447$.

Raitviir, A. 1970: Synopsis of the Hyaloscyphaceae. Scripta Mycol. 1:1-116.

Rehm, H. 1887-1896: Ascomyceten: Hysteriaceen und Discomyceten. - in: L. Rabenhorst's Krypt.-F1. von Deutschland, Österreich und der Schweiz, 2. Aufl. 1(3): $1-1275$

Wehmeyer, L.E. 1961: A world monograph of the genus Pleospora and its segregates. - $451 \mathrm{pp}$. Ann Arbor.

Accepted for publication

on October 22, 1981 